\title{
VEGETATION DESCRIPTION OF THE DOORNHOEK SECTION OF THE Mountain Zebra National Park (MZNP), South Africa
}

\author{
HUGO BEZUIDENHOUT \\ Conservation Sciences \\ South African National Parks \\ South Africa \\ LESLIE R. BROWN \\ Department of Environmental Sciences \\ University of South Africa \\ South Africa \\ Correspondence to: Leslie R. Brown \\ e-mail: lrbrown@unisa.ac.za
}

Postal Address: Applied Behavioural Ecology and Ecosystem Research Unit, Department of Environmental Sciences, University of South Africa, Private Bag X6, Florida, 1710, Republic of South Africa

\begin{abstract}
The Mountain Zebra National Park (MZNP) has been extended over the last couple of years. One of the newly procured areas is the Doornhoek section, which had been adjacent to the park. To develop scientifically sound management programmes for conservation areas, it is essential that an inventory of their natural resources be undertaken. The aim of this study was to classify, describe and map the vegetation of the Doornhoek section of the park. The floristic data were analysed in accordance with the Braun-Blanquet procedures using the BBPC suite. The data analysis resulted in the identification of eight communities, which can be grouped into seven major community types (Rhus lucida-Buddleja glomerata Shrubland, Rhigozum obovatum-Rhus longispina Shrubland, Helichrysum dregeanum-Aristida diffusa Grassland, Pentzia globosa-Enneapogon scoparius Grassland, Aristida adscensionus-Pentzia globosa Grassland, Cadaba aphylla-Acacia karroo Woodland and Lycium oxycarpum-Acacia karroo Woodland). Four of these communities occur on the higher-lying plateau, mid-slope and crest areas, while the other four communities are located on the lower-lying mid-plateau and foot slope, along drainage lines and in valley-bottom areas. The description of the plant communities, together with the vegetation map, can serve as a basis for formulating a management programme for the larger park. Although sections of Doornhoek have been overgrazed and degraded in the past, its recent addition to the MZNP contributes to the available habitat preferred by large herbivores, such as valley bottoms, foot-slopes and plateaux.
\end{abstract}

Keywords: vegetation classification, inventory, Braun-Blanquet, Mountain Zebra National Park (MZNP), Doornhoek

South Africa has an entrenched system of national parks situated within various biomes to protect and manage the ecological integrity of the different ecosystems for present and future generations. One such park, the Mountain Zebra National Park (MZNP), located in the Eastern Cape Province of South Africa, was established in 1937 to preserve the last Cape Mountain Zebra (Equus zebra zebra) population in the Bankberg area of the park. In order to sustain a viable population of these animals, the park area was extended in 1960 and again in 1996, when various farms adjacent to the park were also procured. These newly incorporated areas resulted in the park more than doubling its size from its previous 6536 ha (1960) to approximately 21000 ha.

The park is visited by more than 14000 people annually and has considerable potential to serve as an education centre for environmental education and wildlife management. For any natural area to be managed effectively, it is important that scientifically sound management programmes be developed and implemented. This necessitates an inventory of its natural resources to be undertaken, which enables full quantitative measures of biodiversity to be used to make conservation decisions. A detailed vegetation study of the newly acquired areas of the park was therefore undertaken.

Although extensive studies on various aspects of the vegetation of the old park area were conducted by Van der Walt (1980), Novellie (1990a; 1990b) and Novellie and Bezuidenhout (1994) and also of the De Rust (Brown \& Bezuidenhout, 2000),
Ebenaeser (De Klerk, Brown \& Bezuidenhout, 2003) and Ingleside and Welgedacht (Brown \& Bezuidenhout, 2005) areas, little is known about the vegetation and habitat status of the Doornhoek section.

The aim of this study was therefore to classify, describe and map the vegetation of the Doornhoek section of the park in order to serve as an inventory of the representative ecosystems and their biota. These relatively homogeneous plant communities should form the basis for the compilation of wildlife and ecotourism management plans. This study forms part of a larger and long-term research project undertaken by South African National Parks (SANParks) and the University of South Africa (UNISA) to describe and map the vegetation of each of the newly acquired farms and assess the habitats of these areas for the establishment of large herbivores.

\section{STUDY AREA}

The MZNP is situated approximately $25 \mathrm{~km}$ west of the town of Cradock in the Eastern Cape Province. It extends from latitude $32^{\circ} 05^{\prime}$ to $32^{\circ} 20^{\prime} \mathrm{S}$ and longitude $25^{\circ} 23^{\prime}$ to $25^{\circ} 32^{\prime} \mathrm{E}$ (see Fig. 1). The Doornhoek section comprises 4029 ha and lies approximately $4 \mathrm{~km}$ north of the MZNP.

The vegetation consists of a mixture of dwarf shrubs and grasses with Acacia karroo trees in the lower-lying areas and river beds (Van der Walt 1980). According to Acocks (1988), the 


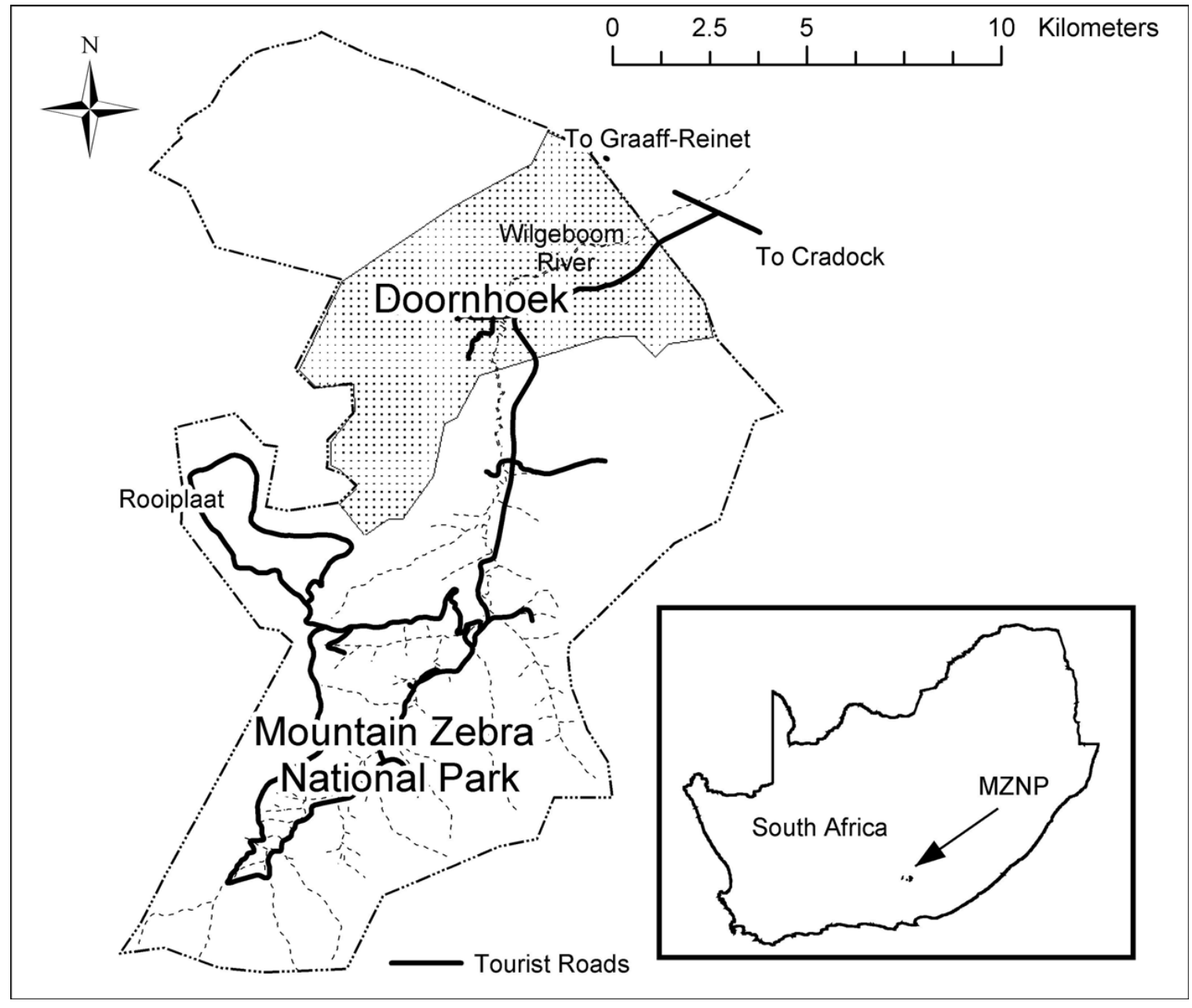

FIGURE 1

Location of the Mountain Zebra National Park (MZNP)

area can be classified as False Karroid Broken Veld (37), while Hoffman (1996) classifies it as Eastern Mixed Nama Karoo (52) Some isolated patches of the South-eastern Mountain Grassland (Grassland Biome) are also found in the study area (Lubke, Bredenkamp \& Van Rooyen, 1996). According to Mucina, Rutherford and Powrie (2005) and Mucina and Rutherford (2006), this vegetation is classified as Eastern Upper Karoo. The terrain is mountainous and comprises lower-lying valleys, drainage lines and river beds, together with steep to moderately steep mountain slopes and relatively flat to undulating plateaux.

\section{Land types with reference to physiography, geology and soil}

Three land types, namely $\mathrm{Da}, \mathrm{Ib}$ and Fc, occur in the Doornhoek section of the MZNP. According to the Land Type Survey Staff (1986), "A land type denotes an area that can be shown at 1:250 000 scale and that displays a marked degree of uniformity with respect to terrain form, soil pattern and climate". A remarkable association between the major plant communities and the different land types of the area has been observed (Bezuidenhout 1993).

According to the Land Type Survey Staff (1986), the D-land type refers to a soil pattern where duplex soils, such as Swartland and Valsrivier forms, are dominant. Without exposed rocks, stones or boulders, more than half of the remaining land must consist of duplex soils. Unit Da refers to land where duplex soils with red $\mathrm{B}$ horizons comprise more than half the area covered by duplex soils. These plains are dominated by plateau midslopes. The geology of this land type is mudstone, shale and sandstone of the Balfour Formation, Beaufort Group of the Karoo Supergroup.
The F-land type refers to pedologically young landscapes, which are predominantly rocky and not alluvial or aeolian. The Fc unit refers to land where lime occurs regularly in upland and valley-bottom soils (Land Type Survey Staff, 1986). Soil forms that epitomise this land type are Glenrosa and Oakleaf. The geology consists of mudstone, shale and sandstone of the Beaufort Group of the Karoo Sequence with rare dolerite intrusions (Land Type Survey Staff, 1999). Two topographical positions are prominent in this terraced landscape, namely the foot slopes and valley bottoms.

The Ib-land type unit refers to exposed rocks, which cover 60 to $80 \%$ of the area. The rocky portions of $\mathrm{Ib}$ may be underlain by soil that would qualify the unit for inclusion in another broad soil pattern had it not been for the surface rockiness. The mid-slopes are the most prominent topographical position in this mountainous landscape, with the dominant soil-rock complex consisting of rock, while the Glenrosa soil form is subdominant. The geology consists of dolerite with mudstone, shale and sandstone of the Balfour Formation, Beaufort Group of the Karoo Supergroup (Land Type Survey Staff, 1999).

\section{Climate}

The average annual rainfall for the area, as measured at the MZNP weather station from July 1962 to June 2004, is $405 \mathrm{~mm}$, with the highest rainfall of $651 \mathrm{~mm}$ and lowest rainfall of $153 \mathrm{~mm}$ being recorded in 1977 and 1966 respectively. During the previous 10 years, the lowest rainfall recorded was $213,4 \mathrm{~mm}$ (in 1992) and the highest $565,5 \mathrm{~mm}$ (in 1991). The average monthly rainfall varies from $11,3 \mathrm{~mm}$ in the dry winter season to $60,8 \mathrm{~mm}$ 


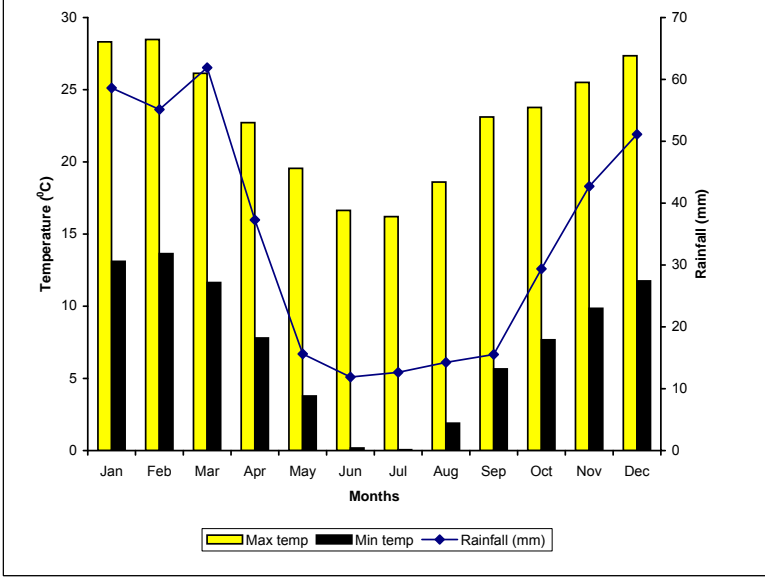

FIGURE 2

Average monthly rainfall and mean average minimum and maximum temperatures as recorded at the Mountain Zebra National Park (MZNP) weather station (rainfall covers the period from July 1962 to June 2005, while temperatures reflect the period from January 1992 to December 1998)

in the wet summer season (see Fig. 2). The average maximum temperature varies between 23,11 and $28,4^{\circ} \mathrm{C}$ in summer (from September to March) and 16,2 and $22,7^{\circ} \mathrm{C}$ in winter (from April to August), while the average minimum temperature varies between 5,6 and $13,6^{\circ} \mathrm{C}$ in summer and 0,05 and 7,8 $8^{\circ} \mathrm{C}$ in winter. The mean average maximum and minimum temperatures are also indicated in Fig. 2.

\section{METHODS}

By using 1:50 000 stereo aerial photographs, the study area was stratified into physiognomic- physiographic units. After a reconnaissance of the area, a total number of 66 sample plots was located on a randomly stratified basis within the different homogeneous units identified from the aerial photographs. The number of sample plots allocated within each homogeneous unit depended on the size of the area, the larger the area the higher the number of sampling plots being allocated to the unit. Plot sizes were fixed at approximately $400 \mathrm{~m}^{2}$ according to Brown (1997). In each sample plot, all species were recorded and the cover abundance of each species was assessed in accordance with the Braun-Blanquet cover-abundance scale (Mueller-Dombois \& Ellenberg, 1974). Plant species identification was done according to Germishuizen and Meyer (2003). Structural terminology was done according to Edwards (1983). The percentage cover of the herbaceous layer (grasses and herbaceous plants), the shrub layer (woody species varying in height between $>0$ to $3 \mathrm{~m}$ ) and the tree layer (woody species higher than $3 \mathrm{~m}$ ) was also estimated.

The habitat information noted, including geology, soil forms, soil depth (shallow $<0,3 \mathrm{~m}$, medium 0,3 to $0,9 \mathrm{~m}$ and deep $>0,9 \mathrm{~m}$ ) and other edaphic factors, slope, aspect and the rockiness of the soil surface of each relevé was qualitatively described. Rock sizes were estimated according to their diameter using the following scale: small (10 to $50 \mathrm{~mm}$ ), medium (50 to $200 \mathrm{~mm}$ ) and large (> $200 \mathrm{~mm})$.

The floristic data were analysed according to Braun-Blanquet procedures using the BBPC suite (Bezuidenhout, Biggs \& Bredenkamp, 1996). The numerical classification program TWINSPAN (Hill, 1979), which several phytosociologists regard as a successful approach for classification (Mucina \& Van der Maarel, 1989; Bredenkamp \& Bezuidenhout, 1995; Cilliers, 1998), was used to derive a first approximation of the floristic data. Further refinement of the classification was achieved by Braun-Blanquet procedures (Bredenkamp, Joubert \& Bezuidenhout, 1989; Kooij, Bredenkamp \& Theron, 1990; Bezuidenhout, 1993; Eckhardt, 1993; Brown \& Bezuidenhout, 2005). Using the phytosociological table and the habitat information gathered during the sampling period, the different plant communities were identified and described according to their dominant species. Dominant species are those that are

\section{Doornhoek- Vegetation Map}

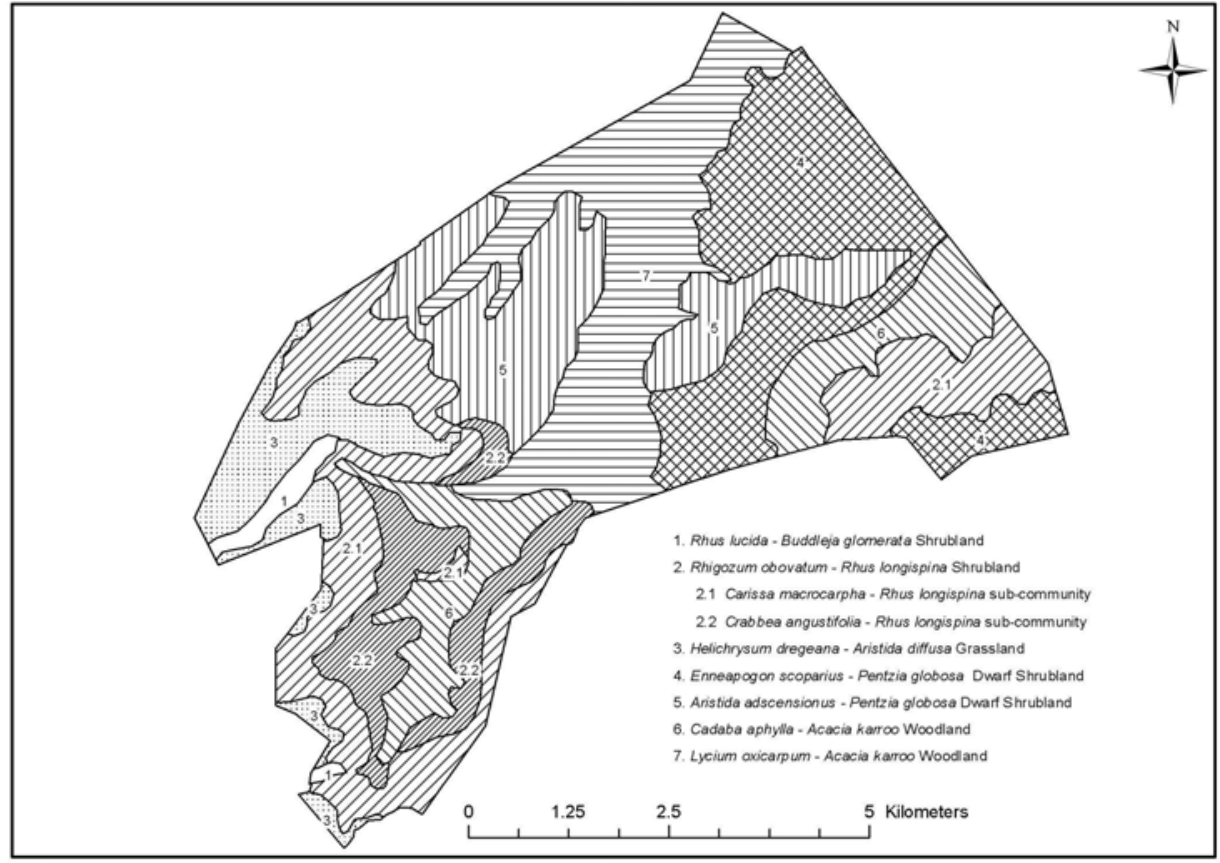

FIGURE 3

Vegetation map for the Doornhoek section of the Mountain Zebra National Park (MZNP) 
most conspicuous in the community and are high in one or more of the importance values (Whittaker, 1978), in this case cover and frequency. No attempt was made to fix syntaxa names formally, as this is normally avoided in detailed local studies (Coetzee, 1983). Soil nomenclature followed the classification of the Soil Classification Working Group (1991).

\section{RESULTS}

\section{Classification}

The data analysis resulted in the identification of eight different communities, which can be grouped into seven major community types. Four of these communities occur on the higher-lying plateau, mid-slope and crest areas, while the other four communities are located on the lower-lying mid-plateau and foot slope, along drainage lines and in valley-bottom areas:

A. Relatively higher-lying vegetation communities on crests and steep slopes:

1. Rhus lucida-Buddleja glomerata Shrubland

2. Rhigozum obovatum-Rhus longispina Shrubland

2.1 Carissa macrocarpa-Rhus longispina Shrubland

2.2 Crabbea angustifolia-Rhus longispina Shrubland

3. Helichrysum dregeanum-Aristida diffusa Grassland

B. Relatively lower-lying vegetation communities on foot slopes and in bottomland areas:

4. Enneapogon scoparius-Pentzia globosa Grassland

5. Aristida adscensionus-Pentzia globosa Grassland

6. Cadaba aphylla-Acacia karroo Woodland

7. Lycium oxycarpum-Acacia karroo Woodland

\section{Description of the plant communities}

A. Relatively higher-lying vegetation communities on crests and steep slopes:

1. Rhus lucida-Buddleja glomerata Shrubland

This shrubland is restricted to the higher mid-slopes. It is characterised by steep slopes with a gradient ranging between 250 and 400 and steep cliffs in some areas. Rock cover is, as expected, high and varies between $55 \%$ and $90 \%$ with shallow, rocky soils sometimes covered by sparse vegetation. This community is associated with the Ib-land type and is the smallest community in the study area, comprising only 53 ha.

Species from species group A (Table 1) are diagnostic for this shrubland and include the trees Olea europaea subsp. africana and Cussonia paniculata, the shrubs Buddleja glomerata, Tarchonanthus camphoratus and Myrsine africana, the dwarf shrub Stachys linearis, the grasses Melinis nerviglumis and Andropogon schirensis, and the forbs Achyranthes spp., Clematis brachiata, Datura stramonium and Pellaea calomelanos. The woody layer comprising mostly large shrubs (1 m tall) ranges in cover between $25 \%$ and $35 \%$, while the herbaceous layer $(0,2 \mathrm{~m}$ tall) has a patchy appearance ranging in cover from $8 \%$ to $50 \%$ in some localities.

The vegetation is dominated by the large shrubs Buddleja glomerata and Rhus lucida (species groups A \& D respectively - Table 1), which typically occurs on rocks and hills (Coates Palgrave 2002). The shrubs Tarchonanthus camphoratus (species group A - Table 1), Gymnosporia buxifolia and Grewia occidentalis (species group F - Table 1) are also prominent although they have relatively low canopy cover. The grasses Melinis repens (species group A - Table 1), Digitaria eriantha, Sporobolus fimbriatus (species group $\mathrm{K}$ - Table 1) and Enneapogon scoparius (species group $\mathrm{K}$ - Table 1) together with the declared weed Datura stramonium (species group A - Table 1) are locally prominent within this community.

Similar communities have been described in the MZNP by Brown and Bezuidenhout (2000; 2005) and De Klerk et al. (2003).
These communities are all associated with steep cliffs, large rocks and boulders, shallow soil, and sparse vegetation cover.

\section{Rhigozum obovatum-Rhus longispina Shrubland}

The Rhigozum obovatum-Rhus longispina Shrubland encompassing 1078 ha in size, is located on the mountain foot slopes and steep mid-slopes mainly within the southern and eastern sections of the Doornhoek section. The gradient on the mountain mid-slopes is mild to steep, while the foot slopes are generally flat with a slight gradient. The presence of species from species group B (Table 1) is characteristic, while the vegetation is dominated by the shrub Rhus longispina (species group B - Table 1) and the grass Aristida diffusa (species group I - Table 1).

This community can be divided into two sub-communities, namely the Carissa macrocarpa-Rhus longispina Shrubland and the Crabbea angustifolia-Rhus longispina Shrubland.

\subsection{Carissa macrocarpa-Rhus longispina Shrubland}

This sub-community (763 ha) is restricted to the mid-slopes and some mid-plateau areas of the study area and is associated with the Ib-land type. The dominant soil-rock complex consists of rock, while the Mispah-soil form is subdominant with a $30 \%$ to $55 \%$ rock cover. The mild to steep gradient varies between $10^{\circ}$ and $21^{\circ}$.

The sub-community is characterised by the presence of species from species group $C$ (see Table 1) and includes the shrubs Carissa macrocarpa, Boscia oleoides, Ehretia rigida and Pappea capensis, the dwarf shrub Lantana rugosum, the grasses Cenchrus ciliaris, Eustachys paspaloides and Eragrostis trichophora, and the forbs Boophane disticha, Cheilanthes hirta, Phyllanthus madagascariensis, Hermannia cernua, Asparagus burchellii and Opuntia ficus-indica. The woody layer consists mainly of shrubs between $2 \mathrm{~m}$ and $3 \mathrm{~m}$ tall with a canopy cover of $10 \%$ to $25 \%$, while the herbaceous layer covers between $35 \%$ and $50 \%$ of the area with an average height of $0,45 \mathrm{~m}$.

The vegetation is dominated by the shrub Rhus longispina (species group B - Table 1) and the grass Aristida diffusa (species group I - Table 1), while the shrub Rhus lucida (species group D - Table 1) and the grasses Cymbopogon pospischilii (species group H - Table 1), Setaria sphacelata, Heteropogon contortus (species group I), Enneapogon scoparius and Aristida adscensionis (species group $\mathrm{K}$ ) are prominent. Other species present include the tree Acacia karroo (species group $\mathrm{P}$ - Table 1), the shrub Grewia occidentalis (species group F - Table 1) and the dwarf shrub Eriocephalus ericoides (species group I - Table 1), which are locally prominent throughout the community.

The community is similar to the Enneapogon scoparius-Ehretia rigida Shrubland in the De Rust section (Brown \& Bezuidenhout, 2000), the Setaria sphacelata-Rhus longispina sub-community in the Ebenaeser section (De Klerk et al., 2003) and the Rhus lucida-Carissa macrocarpa Shrubland in the Ingleside section (Brown \& Bezuidenhout, 2005) of the park. The sub-community comprises medium to large boulders with shallow soil and was prone to overgrazing by angora goats previously present in the Doornhoek section.

\subsection{Crabbea angustifolia-Rhus longispina Shrubland}

Located on the foot slopes of the mountains in the southern section of the study area, this shrubland (315 ha) occurs in deeper Mispah soil than the Cymbopogon pospischilii-Rhus longispina Shrubland (sub-community 2.1). Rock cover is lower ranging, between $20 \%$ and $40 \%$, and consists of small to medium-sized rocks. This sub-community is associated with the Ib-land type.

The vegetation is characterised by the presence of the forbs Crabbea angustifolia, Sutera halimifolia and Hibiscus trionum 


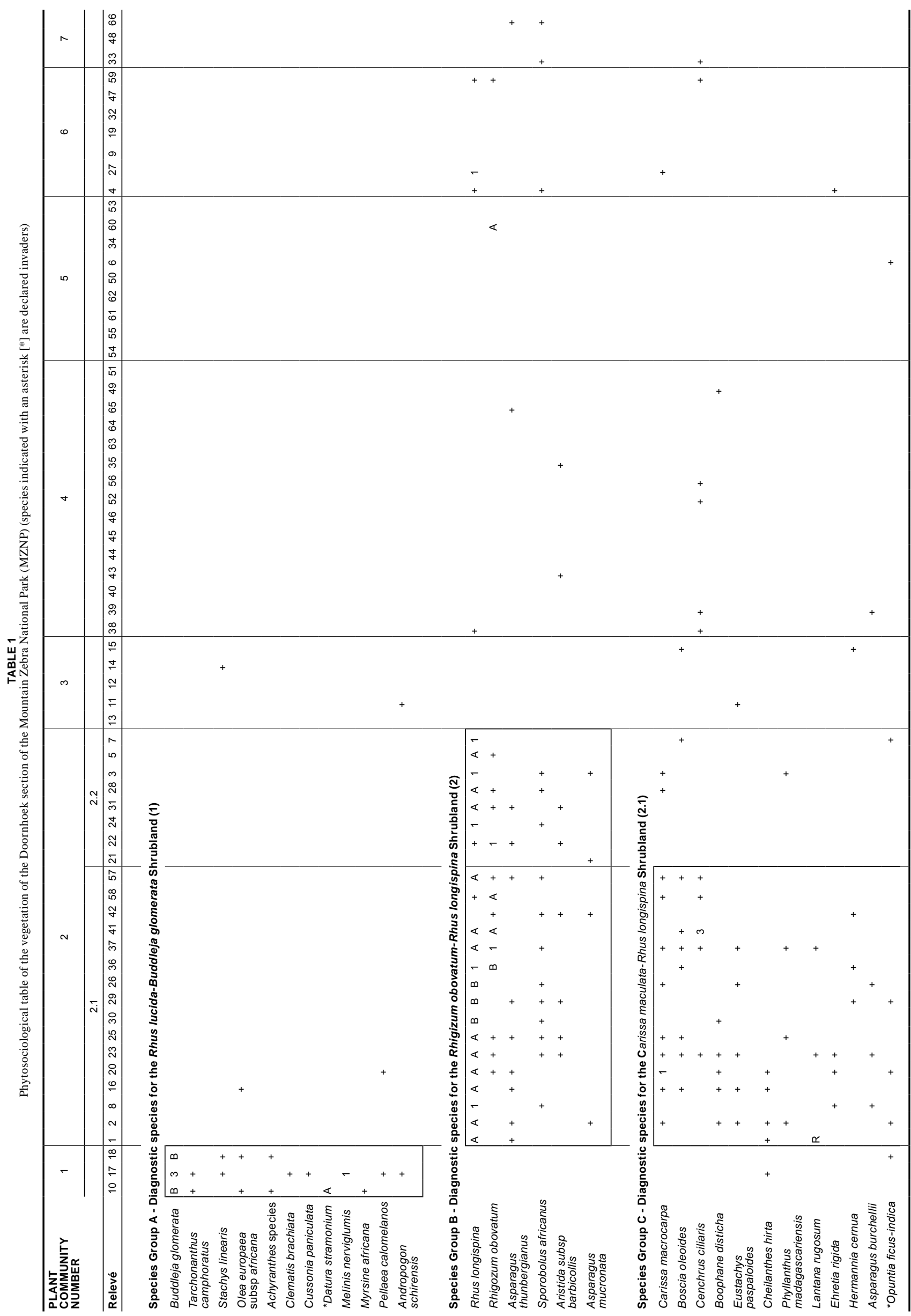




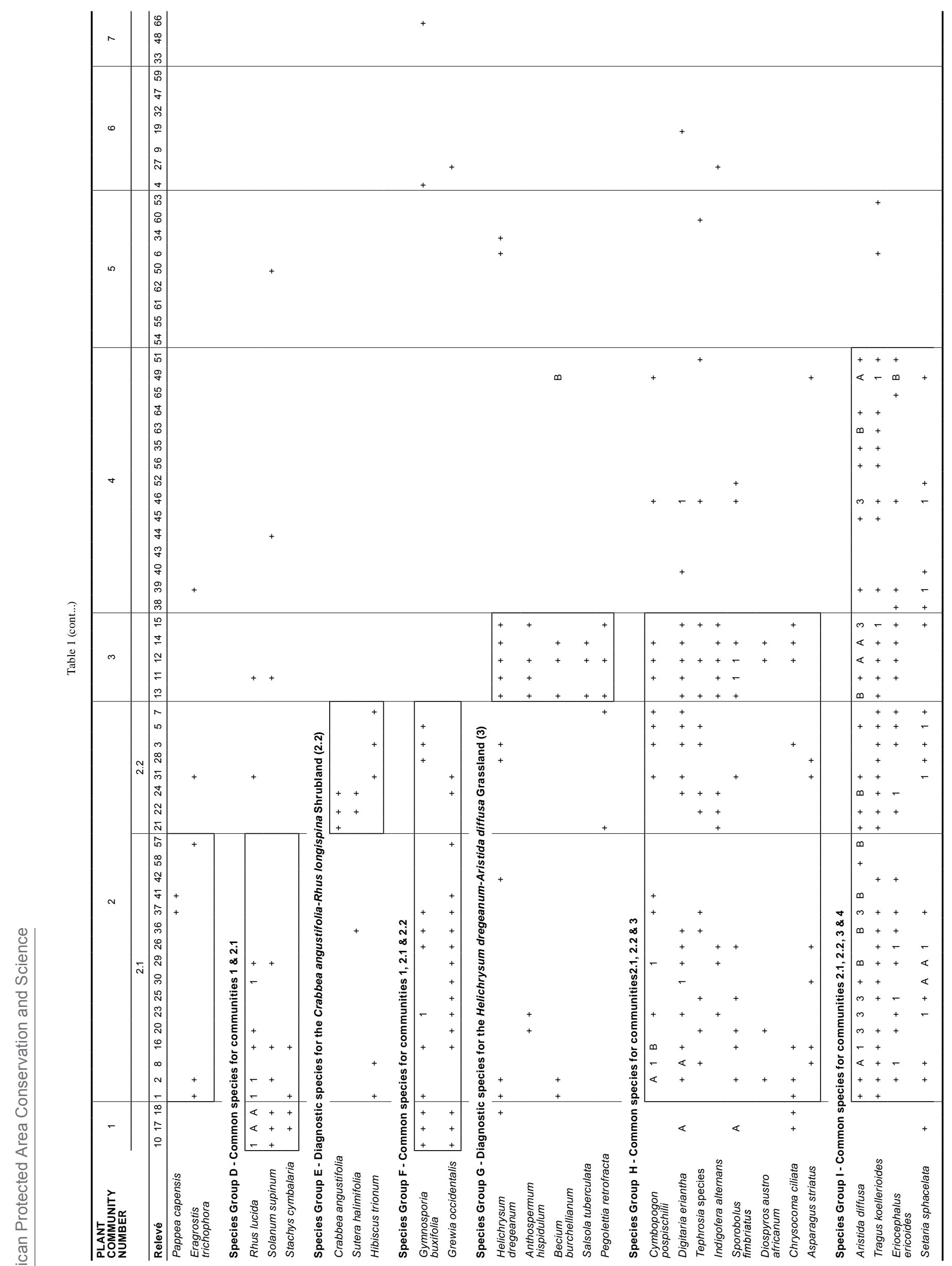




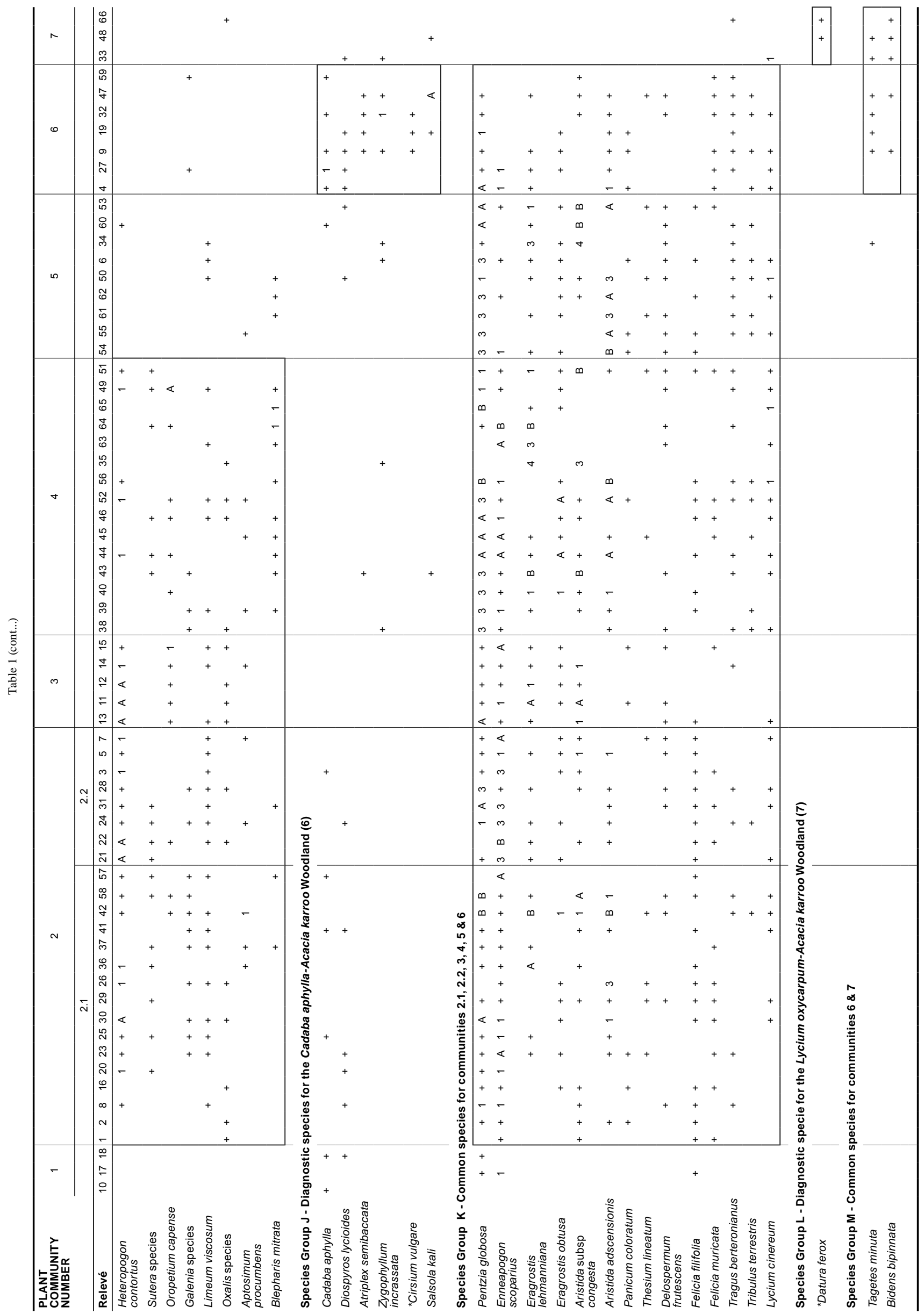




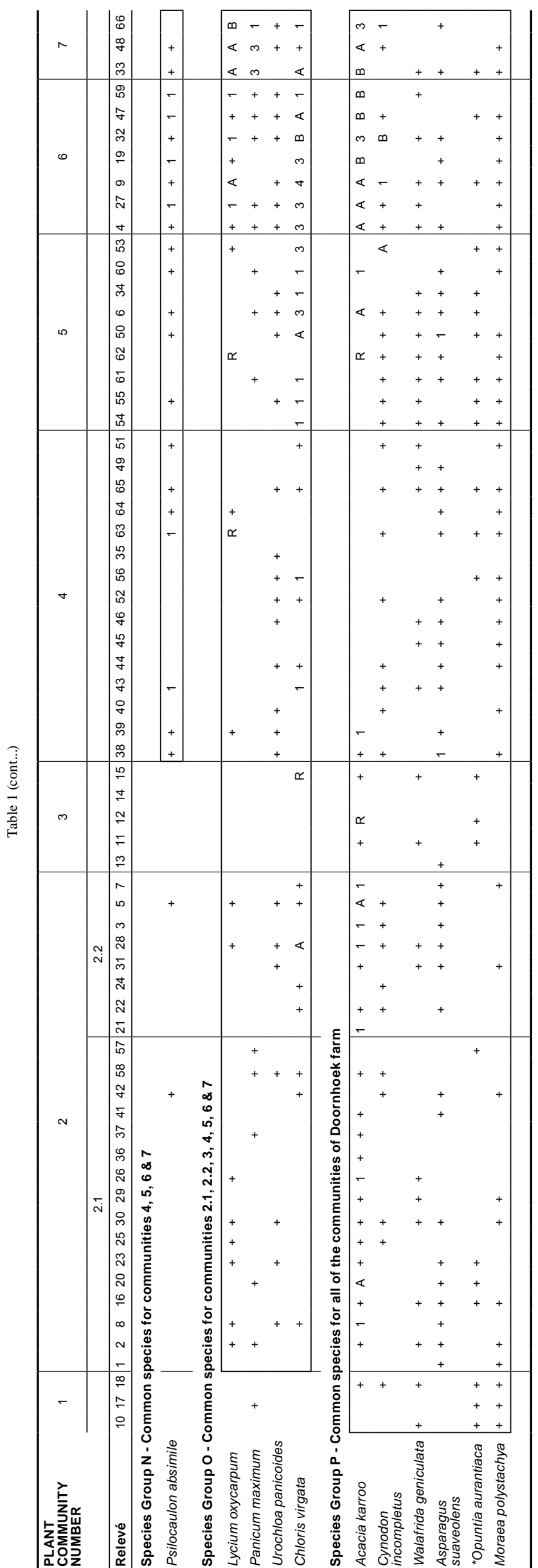

(species group E - Table 1). There are no trees present and the shrub layer, which is between $1,5 \mathrm{~m}$ and $2 \mathrm{~m}$ tall, ranges in canopy cover between $5 \%$ and $10 \%$. The herbaceous layer is dominant and has a canopy cover of $20 \%$ to $45 \%$ and is approximately $0,4 \mathrm{~m}$ tall.

This sub-community is dominated by the shrub Rhus longispina (species group B - Table 1) and the grass Enneapogon scoparius (species group K - Table 1). The tree Acacia karroo (species group P - Table 1), the dwarf shrub Pentzia globosa (species group $\mathrm{K}$ - Table 1) and the grass Heteropogon contortus are codominants within this sub-community. Other species also present include the shrub Rhigozum obovatum (species group B - Table 1), the dwarf shrub Eriocephalus ericoides (species group I - Table 1) and the grasses Aristida diffusa, Setaria sphacelata (species group I - Table 1) and Chloris virgata (species group O - Table 1).

The sub-community shows similarities with the Enneapogon scoparius-Ehretia rigida Shrubland of the De Rust section (Brown \& Bezuidenhout, 2000), although the latter is present on plateau mid-slopes, and the Setaria sphacelata-Rhus longispina subcommunity in the Ebenaeser section (De Klerk et al., 2003).

\section{Helichrysum dregeanum-Aristida diffusa Grassland}

This grassland community, which is only 305 ha in size, is found on the higher-lying plateau areas located in the southwestern section of the study area. The soil is shallow, with small to medium-sized rocks, covering between $10 \%$ and $20 \%$ of the area and occurs on the Da-land type. Smaller sections with slightly deeper soil are also present, although localised in distribution.

The community is characterised by the presence of species from species group G (Table 1), namely the dwarf shrubs Helichrysum dregeanum, Becium burchellianum, Salsola tuberculata and Pegolettia retrofracta and the forb Anthospermum hispidulum. The tree and shrub layers are not well developed, with only a few single individuals present and a total canopy cover of approximately $1 \%$ to $3 \%$. The grass layer has an approximately $35 \%$ canopy cover and an average height of $0,4 \mathrm{~m}$.

The vegetation is dominated by the grasses Aristida diffusa and Heteropogon contortus (species group I - Table 1). Prominent species include the dwarf shrub Pentzia globosa and the grasses Enneapogon scoparius, Eragrostis lehmanniana and Aristida congesta subsp. congesta (species group K - Table 1). The absence of species from species group $\mathrm{O}$, which is present in almost all the other communities, is also a feature of this community, while the dwarf shrub Salsola tuberculata (species group G - Table 1) occurs only within this community. The dominant grasses Aristida diffusa and Heteropogon contortus form dense stands that are evenly dispersed throughout the community. The grasses Oropetium capense and Tragus koellerioides (species group I-Table 1) are also present and are prominent in patches locally, while the dwarf shrub Helichrysum dregeanum (species group $\mathrm{G}$ - Table 1) is present throughout the community.

No similar communities have been described in previous studies in the De Rust, Ebenaeser, Ingleside and Welgedacht sections of the park.

B. Relatively lower-lying vegetation communities on foot slopes and bottom-land areas:

\section{Pentzia globosa-Enneapogon scoparius grassland}

The Pentzia globosa-Enneapogon scoparius Grassland occurs on the mid-plateau and foot-slope areas adjacent to the drainage lines located in the north-eastern section of the study area. It is associated with the Fc-land type and the dominant soil form is shallow Mispah, while the medium-deep Oakleaf soil form occurs in the lower-lying areas. The soil is gravelly and 
small rocks cover between $5 \%$ and $50 \%$ of the surface. This community, which has a total size of 786 ha, comprises $20 \%$ of the study area.

The community has no distinguishing species group but the presence of both species groups I and K (see Table 1) is characteristic. No trees are present and the herbaceous layer, which has an average height of $0,3 \mathrm{~m}$, has a canopy cover ranging between $30 \%$ and $60 \%$.

The vegetation is dominated by the dwarf shrub Pentzia globosa and the grasses Enneapogon scoparius and Eragrostis lehmanniana (species group $\mathrm{K}$ - Table 1). The grasses Eragrostis obtusa and Aristida adcensionis (species group $\mathrm{K}$ - Table 1) and the grass Aristida diffusa (species group I - Table 1) are prominent in large sections of the community. The small shrub Lycium cinereum (species group $\mathrm{K}-$ Table 1 ) is prominent locally.

The community shows similarities with the Eragrostis obtusaPentzia globosa sub-community of the Ebenaeser section (De Klerk et al., 2003) and the Eragrostis obtusa-Pentzia globosa Shrubland on the farms Ingleside and Welgedacht (Brown \& Bezuidenhout, 2005). Locally, some patches are dominated by the increaser 2 grasses Aristida congesta subsp. congesta (species group $\mathrm{K}$ - Table 1) and Chloris virgata (species group $\mathrm{O}$ - Table 1) (Van Oudtshoorn, 2004). These patches were heavily grazed in the past by goats and sheep, leading to the presence of these pioneer grasses.

\section{Aristida adscensionus-Pentzia globosa Grassland}

This open grassland is found in the central and western sections of the study area in the lower-lying valley bottoms and floodplain areas associated with the Fc-land type. The community is 589 ha in size and has low rock cover varying between $0 \%$ and $10 \%$. The dominant soil forms are Hutton and Oakleaf.

This community is characterised by the presence of species from species group $\mathrm{K}$ and the absence of species from species group I (Table 1$)$. Only a few trees $(2 \mathrm{~m}$ to $3 \mathrm{~m}$ tall) are present and they have a total canopy cover of approximately $1 \%$, while the shrub layer ( $1 \mathrm{~m}$ to $2 \mathrm{~m}$ tall) has a cover of approximately $5 \%$. The herbaceous layer between $0,2 \mathrm{~m}$ and $0,45 \mathrm{~m}$ tall has an average canopy cover of $43 \%$ and ranges between $35 \%$ and $70 \%$.

The vegetation is dominated by the dwarf shrub Pentzia globosa (species group $\mathrm{K}$ - Table 1 ) and the grass Chloris virgata (species group $\mathrm{O}$ - Table 1). Prominent species include the grasses Aristida adscensionis, Enneapogon scoparius, Aristida congesta subsp. congesta and Eragrostis lehmanniana (species group $\mathrm{K}$ - Table 1). The spreading shrub Psilocaulon absimile (species group $\mathrm{N}$ - Table 1 ) is present in some localities within this community.

Similar communities have been described in the De Rust section (Psilocaulon junceum-Eragrostis lehmanniana Grassland) and Ingleside and Welgedacht sections (Chloris virgata-Cynodon incompletus Grassland) by Brown and Bezuidenhout (2000; 2005). This community forms part of the larger drainage lines within the study area. Various soil barriers, however, were constructed within the community, probably to prevent erosion during floods. This, together with overgrazing, has resulted in the area becoming degraded and dominated by a large number of prominent pioneer-plant species, such as Aristida congesta subsp. congesta, Chloris virgata, Psilocaulon absimile and Cynodon incompletus (species groups $\mathrm{K}, \mathrm{O}, \mathrm{N}$ and $\mathrm{P}$ - Table 1). Termite mounds were also noted in some localities of the community.

\section{Cadaba aphylla-Acacia karroo Woodland}

This community (439 ha in extent) is located in the narrow drainage lines between the mountains in the southern and eastern sections of the study area. It is associated with the Da-land type and the dominant soil form is Oakleaf. Not much rock is present, small rocks covering approximately $3 \%$ of the area.

The vegetation is characterised by the presence of the shrubs Diospyros lycioides and Cadaba aphylla, the dwarf shrubs Atriplex semibaccata, Zygophyllum incrassata and Salsoli kali and the forb Cirsium vulgare (species group J - Table 1). The tree layer, which is taller than $3 \mathrm{~m}$, has a canopy cover of between $1 \%$ and $50 \%$, the shrub layer ( $1 \mathrm{~m}$ to $3 \mathrm{~m}$ tall) between $5 \%$ and $25 \%$ and the grass layer (0,2 $\mathrm{m}$ to $0,5 \mathrm{~m}$ tall) between $15 \%$ and $50 \%$.

The vegetation is dominated by the trees Acacia karroo and Lycium oxycarpum (species groups $\mathrm{P}$ and $\mathrm{O}$ respectively - Table 1), the grass Chloris virgata (species group $\mathrm{O}$ - Table 1) and the spreading shrublet Psilocaulon absimile (species group $\mathrm{N}$ - Table 1). The shrub Cadaba aphylla (species group J - Table 1), although present in sparse stands in communities 1 and 2 (Table 1), has a high constancy - 71\% - within this woodland. Cadaba aphylla is a preferred shrub and is utilised frequently by ungulates, which adds to this community being preferred by herbivores. It is also an important source of nectar for various bird and insect species (Le Roux, Kotzé, Nel \& Glen, 1994).

The community shows similarities with the Sporobolus africanus-Acacia karroo Woodland (Brown \& Bezuidenhout, 2000), Setaria sphacelata-Cadaba aphylla Shrubland (De Klerk et al., 2003) and Panicum maximum-Acacia karroo Woodland (Brown \& Bezuidenhout, 2005) of the De Rust, Ebenaeser, and Ingleside and Welgedacht sections of the park. None of these three communities, however, is as degraded as this woodland, having more climax and fewer pioneer species.

\section{Lycium oxycarpum-Acacia karroo Woodland}

The Lycium oxycarpum-Acacia karroo Woodland is located in large, open drainage lines and the valley bottom in the central part of the study area. This large community is 779 ha in size and is associated with the Fc-land type. The dominant soil form is Oakleaf and no rocks are present on the surface.

The herbaceous annual and declared weed Datura ferox (species group L - Table 1) is characteristic of this community and typically occurs in drainage channels and river beds (Henderson, 2001). The tree layer has a canopy cover of $20 \%$ and is taller than $4 \mathrm{~m}$, while the shrub layer covers between $20 \%$ and $40 \%$ of the area and is between $2 \mathrm{~m}$ and $3 \mathrm{~m}$ tall. The welldeveloped herbaceous layer, dominated by grasses up to $0,7 \mathrm{~m}$ tall, has an $80 \%$ canopy cover.

The vegetation is dominated by the trees Acacia karroo (species group P - Table 1) and Lycium oxycarpum and the grass Panicum maximum (species group $\mathrm{O}-$ Table 1 ). The grasses Chloris virgata (species group $\mathrm{O}$ - Table 1) and Cynodon incompletus (species group $\mathrm{P}-$ Table 1 ) are prominent.

This community is similar to community 6 but differs in that the spreading shrub Psilocaulon absimile (species group N-Table 1) is not as prominent and the shrub Cadaba aphylla (species group J - Table 1) together with the dwarf shrub Pentzia globosa (species group $\mathrm{K}$ - Table 1 ) are absent. The climax grass Panicum maximum (species group $\mathrm{O}-$ Table 1 ) is also dominant within this woodland, while it is merely present and even absent in community 6 .

Thus, although similar to community 6, which also occurs in drainage lines, this community is not as degraded and therefore has a greater similarity with the Sporobolus africanusAcacia karroo Woodland (Brown \& Bezuidenhout, 2000), the Setaria sphacelata-Cadaba aphylla Shrubland (De Klerk et al., 2003) and the Panicum maximum-Acacia karroo Woodland (Brown \& Bezuidenhout, 2005) of the De Rust, Ebenaeser, and Ingleside and Welgedacht sections of the park. 


\section{DISCUSSION}

The general vegetation of the study area is characterised by the presence and, in some areas, the dominance of the tree Acacia karroo and the dwarf shrub Pentzia globosa, while the grasses Cynodon dactylon and Enneapogon scoparius are also present in most of the plant communities. Large sections of the vegetation, especially in the lower-lying areas, were overgrazed due to previous farming practices with angora goats and sheep. The higher-lying areas were less prone to overgrazing, although patches do occur within the plateau areas where overgrazing did occur.

The different plant communities identified and described are clearly distinguishable from each other in the field as separate vegetation units. Plant communities 1, 2 and 3 are characteristic of the higher-lying areas, which have high rock cover and shallow soil. In contrast, communities 4,5 and 6 are found on the lower-lying areas, which have low rock cover and deeper soil.

Plant community 1 is characteristic of the higher-lying areas on the escarpment, which has very steep $\left(25^{0}\right.$ to $\left.28^{\circ}\right)$ upper slopes and high rock cover, ranging between $50 \%$ and $90 \%$, and shallow soil. The woody layer is the most prominent layer and is dominated by the shrub Buddleja glomerata. Plant community 2 is located on the steep mid-slopes, which have high rock cover and shallow soil. The woody layer is still prominent and is dominated by the tall shrub Rhus longispina, which is conspicuous on all the mid-slopes in the study area. The herbaceous layer is more prominent, covering up to $50 \%$ of the area, and is dominated by the grass Aristida diffusa. Located on the higher-lying plateau areas in shallow to medium-deep soil with a $10 \%$ to $20 \%$ rock cover is the Helichrysum dregeanum - Aristida diffusa grassland (plant community 3). This grassland was prone to overgrazing, which is evident in the plant species composition, where the vegetation is dominated by the grasses Aristida diffusa and Heteropogon contortus.

Plant community 4 is located on the lower-lying mid-plateau and rocky foot-slope areas next to the drainage lines. The soil is deeper than that of the higher-lying areas (communities 1,2 and 3) and has smaller rocks and lower rock cover. The vegetation is dominated by the dwarf shrub Pentzia globosa and grass Enneapogon scoparius. Both communities 6 and 7 are associated with the drainage lines, which have little to no rock cover and deep alluvial soil. These areas were intensively grazed in the past and many pioneer species are therefore present. Plant community 7 has better vegetation cover and composition, although sections were also overutilised in the past.

The presence of dense stands of the declared weed Opuntia aurantiaca throughout the study area is a reason for concern. This species is not present in such large numbers in the old section of the park and the possibility exists that it could spread from here into the old section. Management of the park, in collaboration with Working for Water, has been actively involved in the eradication of this invasive species but it is recommended that monitoring plots be marked to monitor the recovery and/ or spread of this species. This species poses a huge threat to the environment in that it can replace the natural vegetation, thereby altering the functioning of the natural ecosystem.

Communities 5, 6 and 7 are all degraded due to previous overgrazing as a result of angora goat and sheep-farming practices. The degraded condition of these communities is indicated by the presence of a high number of pioneer and weedy species, such as Psilocaulon absimile, Cynodon incompletus, Aristida congesta subsp. congesta, Chloris virgata, Urochloa panicoides, Tagetes minuta, Bidens bipinnata and Cirsium vulgare. Due to communities 6 and 7 being located in the drainage lines, they are also prone to disturbance from floods after heavy rainfall. The deeper and more fertile soil of these areas is responsible for the plants occurring here being more palatable. This, in turn, results in animals congregating in these areas, which causes further degradation. These areas will therefore have to be monitored regularly once game is relocated here to ensure that they are not overutilised and the stocking rates will have to be such that they allow the vegetation to recover.

\section{Concluding remarks}

The Braun-Blanquet approach proved to be an accurate and effective way whereby floristically defined plant communities could be classified and identified in the field. A total of eight different, clearly recognisable plant communities, which can be grouped into seven major communities, were identified and described for the study area. The Doornhoek section, although overgrazed and degraded in sections, increases the area available for large herbivores, especially the valley bottom, foot slope and plateau areas.

An understanding of the plant communities and their associated habitats is of fundamental importance for devising sound management and conservation strategies. The description of the plant communities, together with the vegetation map, can serve as a basis for formulating a management programme for this section of the park as well as the larger park. The data obtained from this study will be incorporated into the existing vegetation map and management plan for the MZNP as part of a larger project undertaken by UNISA and SANParks.

\section{ACKNOWLEDGEMENTS}

The following individuals and institutions are sincerely thanked: National Research Foundation (NRF) and UNISA for financing this study; SANParks, especially the management of the MZNP, for allowing and encouraging the research; $\mathrm{Mr}$ Johan de Klerk for his dedication and support of this project; Dr Stephen Holness for assistance with the maps; Mr Ernest Daemane (Kimberley South African National Parks Herbarium) for verifying the plant species names; and GN Dithlale (UNISA) for assistance with the species data analysis.

\section{REFERENCES}

Acocks, J.P.H. 1988. Veld types of South Africa. 3rd ed. Memoirs of the Botanical Survey of South Africa, 57: 1-146.

Bezuidenhout, H. 1993. Syntaxonomy and synecology of Western Transvaal grasslands. PhD dissertation, University of Pretoria, Pretoria.

Bezuidenhout, H., Biggs, H.C. \& Bredenkamp, G.J. 1996. A process supported by the utility BBPC for analysing Braun-Blanquet data on a personal computer. Koedoe, 39(1): 107-112.

Bredenkamp, G.J. \& Bezuidenhout, H. 1995. A proposed procedure for the analysis of large data sets in the classification of South African grasslands. Koedoe, 38(1): 33-39.

Bredenkamp, G.J., Joubert, A.F. \& Bezuidenhout, H. 1989. A reconnaissance survey of the vegetation of the plains in the Potchefstroom-Fochville-Parys area. South African Journal of Botany, 55(2): 199-206.

Brown, L.R. 1997. A plant ecological and wildlife management plan for the Borakalalo Nature Reserve, North West Province. PhD dissertation, University of Pretoria, Pretoria.

Brown, L.R \& Bezuidenhout, H. 2000. The phytosociology of the farm De Rust in the Mountain Zebra National Park, Eastern Cape. Koedoe, 43(1): 1-18.

Brown, L.R \& Bezuidenhout, H. 2005. A vegetation description and classification of the farms Ingleside and Welgedacht in 
the Mountain Zebra National Park, Eastern Cape. Koedoe, 48(2): 23-42.

Coates Palgrave, M.C. 2002. Keith Coates Palgrave trees of Southern Africa. Cape Town: Struik.

Coetzee, B.J. 1983. Phytosociology, vegetation structure and landscapes of the central district, Kruger National Park. Dissertationes Botanicae, 69: 1-456.

Cilliers, S.S. 1998. Phytosociological studies of urban open spaces in Potchefstroom, North West Province, South Africa. PhD thesis, Potchefstroom University for CHE, Potchefstroom.

De Klerk, J., Brown, L.R. \& Bezuidenhout, H. 2003. Plant communities of the Ebenaeser section of the Mountain Zebra National Park. Koedoe, 46(2): 1-13.

Eckhardt, H.C. 1993. A synecological study of the vegetation of the north-eastern Orange Free State. MSc thesis, University of Pretoria, Pretoria.

Edwards, D. 1983. A broad-scale structural classification of vegetation for practical purposes. Bothalia, 14: 705-712.

Germishuizen, G. \& Meyer N.L. (eds.). 2003. Plants of Southern Africa: An annotated checklist. Strelitzia, 14.

Henderson, L. 2001. Alien weeds and invasive plants. Plant Protection Research Institute handbook no. 12. Cape Town: Agricultural Research Council.

Hill, M.O. 1979. TWINSPAN: A FORTRAN program for arranging multivariate data in an ordered two-way table by classification of the individuals and attributes. New York: Cornell University.

Hoffman, T. 1996. Eastern mixed Nama Karoo, in A.B. Low \& A.G. Rebelo (eds.). Vegetation of South Africa, Lesotho and Swaziland. Pretoria: Department of Environmental Affairs and Tourism.

Kooij, M.S., Bredenkamp, G.J. \& Theron, G.K. 1990. Classification of the vegetation of the B land type in the north-western Orange Free State. South African Journal of Botany, 56: 309-318.

Land Type Survey Staff. 1986. Land types of the maps SE27/20 Witdraai, 2720 Noenieput, 2722 Kuruman, 2724 Christiana, 2820 Upington, 2822 Postmasburg. Memoirs of the Agricultural Natural Resources of Southern Africa, 3: 1-185.
Land Type Survey Staff. 1999. Land types occurrence (maps) and areas of 3224 Graaff-Reinet. Unpublished information from the Institute for Soil, Climate and Water, Pretoria.

Le Roux, P.M., Kotzé, C.D., Nel, G.P. \& Glen, H.F. 1994. Bossieveld, grazing plants of the Karoo and karoo-like areas. Bulletin, 428.

Lubke, R., Bredenkamp, G.J. \& Van Rooyen, N. 1996. Southeastern mountain grassland, in A.B. Low \& A.G. Rebelo (eds.). Vegetation of South Africa, Lesotho and Swaziland. Pretoria: Department of Environmental Affairs and Tourism.

Mucina, L. \& Rutherford, M.C. (eds.). 2006. Vegetation of South Africa, Lesotho and Swaziland. Strelitzia, 19.

Mucina, L., Rutherford, M.C. \& Powrie, L.W. (eds.). 2005. Vegetation map of South Africa, Lesotho and Swaziland, 1:1 000000 scale sheet maps. Pretoria: South African National Biodiversity Institute.

Mucina, L. \& Van der Maarel, E. 1989. Twenty years of numerical syntaxonomy. Vegetation, 81: 1-15.

Mueller-Dombois, D. \& Ellenberg, H. 1974. Aims and methods of vegetation ecology. New York: Wiley.

Novellie, P. 1990a. Habitat use by indigenous grazing ungulates in relation to sward structure and veld condition. South African Journal of Wildlife Research, 7(1): 16-23.

Novellie, P. 1990b. The impact of a controlled burn on Karroid Merxmuellera mountain veld in the Mountain Zebra National Park. South African Journal of Ecology, 1: 33-37.

Novellie, P.A. \& Bezuidenhout, H. 1994. The influence of rainfall and grazing on vegetation changes in the Mountain Zebra National Park. South African Journal of Wildlife Research, 24(3): 60-71.

Soil Classification Working Group. 1991. Soil classification: A taxonomic system for South Africa. Memoirs on the Agricultural Natural Resources of South Africa, 15: 1-262.

Van der Walt, P.T. 1980. A phytosociological reconnaissance of the Mountain Zebra National Park. Koedoe, 23: 1-32.

Van Oudtshoorn, F. 2004. Guide to grasses of Southern Africa. Pretoria: Briza Publications.

Whittaker, R.H. 1978. Dominance types, in R.H. Whittaker (ed.). Classification of plant communities. The Hague. 